\title{
Educational Inequalities in Labor Market Exit of Older Workers in 15 European Countries
}

\author{
JANA MÄCKEN* (D, PATRICK PRÄG**, MORITZ HESS*** AND \\ LEA ELLWARDT ${ }^{* * * *}$
}

*University of Cologne, Albertus-Magnus-Platz, 50923 Cologne

email: maecken@wiso.uni-koeln.de

**CREST, ENSAE, IP Paris, 5 Avenue Le Chatelier, 91764 Palaiseau email: patrick.prag@

ensae.fr

*** University of Applied Sciences Niederrhein, Richard-Wagner-Str. 101, 41065

Mönchengladbach email: moritz.hess@hs-niederrhein.de

**** University of Cologne, Albertus-Magnus-Platz, 50923 Cologne

email: ellwardt@wiso.uni-koeln.de

Corresponding author. Dr. Jana Mäcken, University of Cologne, Albertus-Magnus-Platz, 50923

Cologne, email: maecken@wiso.uni-koeln.de

\begin{abstract}
This article examines country differences in the association between education and voluntary or involuntary labor market exit and whether these country differences map onto institutional characteristics of the countries. Work exit is defined as involuntary or voluntary based on the reasons of exit. Four different types of institutional factors, push and pull, aiming for an earlier work exit and need and maintain factors to retain older workers in employment are considered. Using data from 15 European countries from the longitudinal Survey of Health, Aging and Retirement in Europe (SHARE), discrete-time event history models with a categorical outcome are estimated for each country separately. In a second step, we add macro-level indicators and conduct meta-analyses to analyze country differences. Results show that in almost all countries a social gradient in involuntary work exit exists but not in voluntary exit. Lower-educated workers are more likely to involuntarily exit the labor market. Institutional factors, especially those supporting older workers' retention in employment, are associated with a smaller social gradient in work exit. Our findings suggest that investments in active labor market expenditures, especially in lifelong learning and rehabilitation for lower educated workers, may help to reduce the social gradient in involuntary work exit.
\end{abstract}

\section{Introduction}

Demographic ageing is threatening the long-term financial sustainably of pay-as-you-go public pension systems, as an increasing number of recipients is facing a shrinking number of contributors. Policymakers all over Europe are implementing pension and labor market reforms aimed at delaying retirement and extending working lives and consequently securing public pensions. Examples for such reforms are an increase of statutory pension ages and the closing of early retirement options. These reforms are taking effect, as actual 
retirement ages and older workers' employment rates are rising all over Europe, however from different starting points and to different extents (Ebbinghaus and Hofäcker, 2013). These measures aiming to extend working lives run the risk of exacerbating social inequalities, as lower and higher educated workers leave the labor market at different ages and for different reasons, potentially widening pension gaps after the end of working lives. Comparing late careers of workers from 15 European countries, this study aims to identify educational differences in work exit and if these differences vary by institutional characteristics.

Most studies analyzing labor market exit found a social gradient. Lowereducated workers leave the labor market earlier while higher educated are more likely to work past the age of 65 years and retire later. For example, workers in the US without a high school degree are five percentage points less likely to plan to work beyond the age of 62 compared to high school graduates, and the lower occupational class has a $\mathbf{1 . 8 2}$ times higher probability of intending to retire compared to higher classes in European countries (Murphy et al., 2007; Wahrendorf et al., 2013). Thus, pension and labor market reforms aimed at extending working lives may affect workers differently depending on their educational qualification. For lower-educated workers, reaching the new goal of extended working lives is more difficult. This may lead to rising social inequalities between lower and higher educated workers, as early work exit reduces old-age pension claims.

Reasons for an early work exit differ between low- and high-educated workers. The lower educated exit the workforce more often early and involuntarily due to ill health, hazardous working conditions, or unemployment (Robroek et al., 2015; van Solinge and Henkens, 2007), whereas the higher educated leave the labor market later and more often voluntarily because of better health and stronger attachment to work (Carr et al., 2018).

Whether a work exit is voluntary or involuntary depends on institutional opportunities and constraints driving the decision to exit the labor market (Radl, 2013). Institutional factors affecting an early work exit can be described as push and pull factors. As policies to retain older workers in employment have gained importance, the approach has been extended by need and maintain factors (Hofäcker and Radl, 2016). Previous research showed that involuntary work exit is more prevalent in countries where push factors are dominant, e.g. high levels of unemployment, whereas in countries supporting pull factors - for example, with low statutory pension ages - older workers tend to exit the labor force more often voluntarily (Ebbinghaus and Radl, 2015).

Little is known about the effect of these institutional factors on different work exit routes of lower and higher educated workers, as previous research focused on single exit routes or was cross-sectional (Carr et al., 2018; Schuring et al., 2019; van Rijn et al., 2014). Furthermore, most countries implemented institutional arrangements supporting late work exit. Until now, the effect of such arrangements on the voluntariness of exit decisions has not been 
explored. Finally, most studies were single-country studies and the majority of these studies were conducted in Northern European countries making it difficult to explore differences in welfare regimes (Schuring et al., 2015; van Rijn et al., 2014). Studies analyzing country differences clustered countries according to welfare regimes, and this potentially hides important country variation. Further, effects cannot be attributed to a specific institutional-level factor. Previous multilevel studies have generated important findings, but recent simulation studies suggested that random-effects models based on few countries tend to overestimate country effects: hence, it is important to revisit findings from these studies (Bryan and Jenkins, 2016; Engelhardt, 2012; Reeuwijk et al., 2017; Schuring et al., 2019).

This study examines (1) country differences in the association between education and voluntary and involuntary labor market exit and (2) whether these country differences map onto institutional characteristics of the countries. We contribute to the existing literature in three ways. First, it is the first study to empirically test institutional factors that also include those aiming at delaying retirement - hence, extending the push and pull approach. Secondly, a metaanalysis is used which can be seen as a more conservative method for testing country differences (Brons et al., 2017; Bryan and Jenkins, 2016). Thirdly, using a longitudinal study-design across 15 European countries and considering different exit routes for higher and lower educated workers, this study may identify institutional measures which can help prolong working lives - especially for workers with lower levels of education - and reduce inequalities between lower and higher educated workers.

\section{Education and labor market exit}

Older workers' decisions when to leave the labor market can be conceptualized as a process in which individuals weigh the benefits and costs of early and late labor market exit, respectively (Hofäcker et al., 2016). Assuming that individuals try to maximize their utility, they decide to exit the labor market when the expected income and leisure time after work exit outweighs staying in work (Visser et al., 2016). Thus, work exit is largely driven by opportunities and constraints of socio-demographic, workplace, and institutional factors.

Education is a main socio-demographic determinant in older workers' exit decisions, as it is linked to several individual-level factors of work exit decisions: for instance, workplace characteristics, labor market changes, income, and health. Lower levels of education have been associated with poorer working conditions, earlier work exit, higher levels of morbidity, and lower disability-free life expectancy (Carr et al., 2018; Wahrendorf et al., 2013). Especially older workers' health is a main reason for work exit, but it is also driven by education and part of the total effect of education, which is of interest in the present study. Thus, 
education is a valid measure that summarizes several interrelated key individuallevel determinants of work exit decisions (Hofäcker and Naumann, 2015).

Better education provides individuals with opportunities to exit the labor market voluntarily - as it is associated with more attractive, more stable, higher-income jobs, and healthier working conditions (Potočnik et al., 2009; Robroek et al., 2015). Only someone who is healthy and has a job can opt for working longer. Furthermore, higher education may be related with a delayed work exit because of later career onset due to longer time spent in formal schooling (Fisher et al., 2016). The lower educated, on the contrary, are facing more constraints as low education is linked to unfavorable working conditions, poorer health, and a higher risk of job loss (Ebbinghaus and Radl, 2015; van Solinge and Henkens, 2007). Hence, the lower and higher educated differ by type of work exit, as the higher educated are able to exit work voluntary. The lower educated, on the other hand, are at higher risk of leaving work involuntarily, e.g. due to job loss or poor health. Previous research in the Netherlands showed that the lower educated are more likely to exit the labor market through involuntary exit routes, such as disability benefits, unemployment, and economic inactivity, but not to early retirement (Robroek et al., 2015). Lower educated Swedish men have a higher risk of receiving a disability pension than those with higher education (Johansson et al., 2012). It can be hypothesized that $\mathrm{H}_{1}$ : the lower educated are at higher risk of involuntary work exit, whereas $H_{1} b$ : the higher educated are at higher risk of voluntary work exit.

\section{Country differences in labor market exit: The push and pull approach}

Besides individual factors contextual opportunities and constraints of welfare state regulations are influential determinants of individuals' decisions to exit the labor market too, as they shape the cost and benefits of early respectively late work exit. Institutional factors driving work exit can be described as push and pull factors. Both factors are aiming for an early work exit but in different ways. Social protection related incentives and the availability of multiple pathways into early work exit are summarized as pull factors. Pull factors provide financially attractive opportunities for workers to leave work early without or only small pension reductions. Assuming that older workers compare the benefits and costs of continuing to work or exiting the labor force, they will choose the financially more attractive option. If early-exit programs compensate forgone wages and future pension benefits, individuals will opt for an early exit rather than keep on working until formal retirement age. Labor market exit of older workers are thus regarded as being mostly voluntary because older workers decide to exit early instead of continuing to work (Hofäcker and Radl, 2016). Previous research showed that countries providing attractive early retirement options have the lowest employment ratios among older workers compared to other countries (Gruber and Wise, 2000; Hofäcker and Radl, 2016). 
In contrast, push factors can be seen as structural labor market constraints that drive older workers involuntarily out of employment (Ebbinghaus and Hofäcker, 2013). Economic downturns or labor demand shocks and the associated increase in the unemployment rate reduce older workers' employment chances and raise the likelihood of an early work exit. Strict employment protection regulations (EPL) may push older workers out of the workforce as firms induce retirement to older workers as a shedding strategy (De Preter et al., 2013; Ebbinghaus and Radl, 2015). Evidence for push factors is mixed. Some studies showed that low levels of economic growth measured with the gross domestic product and high unemployment rates are associated with involuntary work exit (Ebbinghaus and Radl, 2015; Hutchens, 1999). In addition, employment protection regulations seem to have a weak positive effect on involuntary work exit. Other studies found no evidence of the influence of push factors on work exit (De Preter et al., 2013; Ebbinghaus and Hofäcker, 2013).

Yet, not all older workers benefit similarly from such policies, as economic incentives and structural constraints affect lower- and higher-educated workers differently (Blossfeld et al., 2011). Higher educated workers face fewer constraints, healthier working conditions, and high private as well as occupational pension claims, which allow them a voluntary early work exit. In contrast, unfavorable working conditions, lower income and pension claims of lower-educated workers make an early work exit much more difficult (Radl, 2013). Previous research further showed a social gradient in work exit that varies by country context. Lower-educated workers are at greater risk of any type of work exit in France, Finland, USA, the United Kingdom, and the Netherlands (Carr et al., 2018; Scharn et al., 2018). According to the push and pull approach, pull factors should have a stronger influence on low educated workers, as they provide financially attractive opportunities and especially enable low educated workers, who have smaller pension claims compared to higher educated, to retire voluntarily (Radl, 2013). For lower-educated older workers the possibility to retire early is more responsive than for higher-educated older workers for two reasons: first, lower-educated workers face poorer working conditions than those with high education (Wahrendorf et al., 2013) and, hence, exiting the labor market early is more attractive for those with low education; second, highereducated workers identify themselves more strongly with their jobs compared to lower educated workers (Schreurs et al., 2010). Therefore, lower-educated workers can be expected to be more inclined to use the opportunity to retire early with only small pension deductions. Thus, more lower-educated workers can be expected to retire early and do so voluntarily and hence, the social gradient in voluntary work exit should be smaller (see Figure 1). Push factors may affect lower-educated workers more strongly, as they are more vulnerable to economic restricting. This likely increases the social gradient, as lower-educated workers are at higher risk of exiting the labor market involuntarily. To sum 


\begin{tabular}{|c|c|c|c|c|c|}
\hline Hypothesis & Factor & Indicators & $\begin{array}{l}\text { Involuntary } \\
\text { Work Exit }\end{array}$ & $\begin{array}{l}\text { Voluntary } \\
\text { Work Exit }\end{array}$ & $\begin{array}{l}\text { No Work } \\
\text { Exit }\end{array}$ \\
\hline $\mathrm{H} 2 \mathrm{a}$ & Pull & $\begin{array}{l}\text { Passive labor market } \\
\text { expenditures } \\
\text { Formal retirement age }\end{array}$ & Smaller & Smaller & - \\
\hline $\mathrm{H} 2 \mathrm{~b}$ & Push & $\begin{array}{l}\text { Unemployment rate of } \\
\text { older workers } \\
\text { EPL-Index }\end{array}$ & Larger & - & - \\
\hline $\mathrm{H} 2 \mathrm{c}$ & Need & $\begin{array}{l}\text { Net replacement rate } \\
\text { Early retirement options }\end{array}$ & - & - & Smaller \\
\hline $\mathrm{H} 2 \mathrm{~d}$ & Maintain & $\begin{array}{l}\text { Lifelong learning } \\
\text { Active labor market } \\
\text { expenditures } \\
\text { Rehabilitation } \\
\text { expenditures }\end{array}$ & Smaller & Smaller & Smaller \\
\hline
\end{tabular}

FIGURE 1. Hypothesized influence of institutional factors on the social gradient in work exit.

up, it can be hypothesized that $H_{2} a$ : Pull factors are associated with a smaller social gradient in voluntary and involuntary work exit and $\mathrm{H}_{2} b$ : Push factors are associated with a larger the social gradient in involuntary work exit.

\section{Paradigmatic shift from early work exit to active aging: Need and maintain factors}

The push and pull approach, which aimed for an early work exit, has been extended by stay factors (Ebbinghaus and Hofäcker, 2013). Stay factors target a late work exit and were further differentiated into need and maintain factors (Hofäcker and Radl, 2016). Policies supporting older workers' retention in employment are defined as maintain factors. Maintain factors include lifelong learning and active labor market policies aiming at increasing older workers' employability. Furthermore, they also encompass anti-ageism campaigns, and firm incentives to hire or retain older workers. The awareness of such policies has increased during the last years, as policies have undergone a paradigmatic shift from early work exit to active aging (Hofäcker and Radl, 2016). Whereas maintain factors intend to improve opportunities of older workers to stay in employment, the purpose of need factors is explicitly to increase the financial necessity to do so. Need factors comprise recent upward shifts in retirement ages and the monetary punishment of early work exits by pension deductions. Other measures to increase the financial need to remain employed are restricting or closing early-exit pathways, such as disability retirement or unemployment insurance, or general pension level cuts either by delaying access to them, or reducing replacement rates (Hofäcker and Radl, 2016). Both need and maintain factors can be expected to decrease the risk of early work exit, as both are aiming for longer working lives. Need factors should decrease the gap in the employment rate between higher- and lower-educated workers as less education is associated with lower income. Thus, low educated workers, who have fewer 
resources to compensate monetary difficulties, face stronger financial pressures to delay retirement than the higher educated. In addition, maintain factors can be expected to decrease the gap in work exit between lower and higher educated workers. This is because lower-educated workers profit more from training opportunities and active labor market policies compared to the higher educated as they especially increase the employability of lower-educated workers. Highereducated workers often already have a better employability due to their greater human capital (Hess et al., 2016). Consequently, the employment gap should close. It can be hypothesized that $\mathrm{H}_{2} \mathrm{c}$ : Need factors are associated with a smaller social gradient in the employment rate and $\mathrm{H}_{2} \mathrm{~d}$ : Maintain factors are associated with a smaller social gradient in voluntary, involuntary, and no work exit. The following allocation of the indicators to the respective factor is based on Hofäcker and Unt (2013) and Hofäcker and Radl (2016).

\section{Data and Method \\ Data}

The association between education and work exit was investigated with the longitudinal Survey of Health, Aging, and Retirement in Europe (SHARE). The survey collected data of participants aged 50 years and older (Börsch-Supan et al., 2013). Starting with the first wave in 2004 and 2005 in 11 European countries and Israel, follow-ups were conducted biennially until 2017. By now, 28 countries have participated. Our longitudinal analysis was restricted to observations with at least two waves. Hence, eight countries, which started participating in the SHARE during the last wave (7), and thereby had completed only one wave, were excluded. Moreover, in some countries, the sample size was too low to be included in the analysis (Hungary, Croatia, Greece, Luxembourg) with less than 20 involuntary work exits. Israel was excluded because not all macro indicators were available. Our analysis uses data from seven waves and the analytical sample includes 15 countries $^{1}$. Respondents were aged between 50 and 69 and had to be in paid work during the first observation. The sample consists of 19,716 respondents and 131,669 person-years. Country-specific case numbers range from $n=268$ in Portugal to $n=2,179$ in Belgium. We provide a replication package for the analyses on-line (Mäcken et al., 2020).

\section{Outcome variable labor market exit}

Respondents were asked in each wave about their employment status and had several options to choose from. If they exited the labor market, they were asked for the reasons. According to the Hofäcker et al. (2016) classification that we adopted, we consider the following responses to be voluntary or involuntary work exits (Figure 2). If respondents were still employed and no labor market 


\begin{tabular}{|c|c|c|c|c|}
\hline Voluntary work exit & $\%$ & & Involuntary work exit & $\%$ \\
\hline $\begin{array}{l}\text { Became eligible for public, } \\
\text { private, or private occupational } \\
\text { pension }\end{array}$ & $74.7 \%$ & - & Disability retirement & $36.8 \%$ \\
\hline $\begin{array}{l}\text { Was offered an early retirement } \\
\text { option/window }\end{array}$ & $13.6 \%$ & - & Retired due to own ill health & $15.9 \%$ \\
\hline - To enjoy life & $3.9 \%$ & - & $\begin{array}{l}\text { Became unemployed } \\
\text { because you were laid off }\end{array}$ & $13.9 \%$ \\
\hline $\begin{array}{l}\text { To spend more time with } \\
\text { family }\end{array}$ & $3.2 \%$ & - & $\begin{array}{l}\text { Made redundant (for } \\
\text { example pre-retirement) }\end{array}$ & $11.6 \%$ \\
\hline $\begin{array}{l}\text { Became unemployed due to } \\
\text { resigning or a mutual } \\
\text { agreement }\end{array}$ & $2.2 \%$ & - & $\begin{array}{l}\text { Became unemployed } \\
\text { because the place of work or } \\
\text { office closed }\end{array}$ & $9.7 \%$ \\
\hline $\begin{array}{l}\text { To retire at same time as spouse } \\
\text { or partner }\end{array}$ & $1.9 \%$ & • & $\begin{array}{l}\text { Became unemployed } \\
\text { because moved town or } \\
\text { other reasons }\end{array}$ & $5.9 \%$ \\
\hline $\begin{array}{l}\text { Became a homemaker because } \\
\text { wanting to take care of } \\
\text { grandchildren }\end{array}$ & $0.2 \%$ & & $\begin{array}{l}\text { Became unemployed } \\
\text { because a temporary } \\
\text { contract had ended }\end{array}$ & $5.0 \%$ \\
\hline $\begin{array}{l}\text { Became a homemaker because } \\
\text { work was too tiring }\end{array}$ & $0.2 \%$ & - & $\begin{array}{l}\text { Retired due to ill health of } \\
\text { relative or friend }\end{array}$ & $1.2 \%$ \\
\hline $\begin{array}{l}\text { - Became a homemaker because } \\
\text { family income was sufficient }\end{array}$ & $0.1 \%$ & & & \\
\hline
\end{tabular}

FIGURE 2. Reasons for a voluntary and involuntary work exit.

exit occurred, they were treated as censored. Respondents with episodes of unemployment who reported to work again were treated as censored.

\section{Key predictor education}

Education was measured when participants enter the sample. Country-specific educational categories were classified according to the International Standard Classification of Education (ISCED-97) and recoded into low (ISCED 1, 2), medium (ISCED 3, 4) and high (ISCED 5, 6). The social gradient was identified by comparing the difference between the average probability of the lower-educated (ISCED 1, 2) of exiting work involuntarily, voluntarily, or staying employed, compared to higher-educated workers (ISCED 5, 6). Thus, the social gradient is the contrast in the average probability between lower and higher-educated workers of exiting work.

\section{Country-level indicators}

All country level indicators were measured in the first wave for each country when all respondents were still in work. Respondents could exit the labor market thereafter at any time. Using the classification of measures by Hofäcker and Unt (2013) as a starting point, four different institutional factors were measured with at least two indicators each (see Table 2). The categorization of the indicators might not be mutually exclusive as some indicators may capture more than one institutional factor. For this reason, we will test each indicator separately. 
Pull factors: passive labor market expenditures (PLMP) as percentage of GDP for each country were obtained from the OECD (OECD, 2019b). PLMP aim at maintaining the living standard after work exit and encompass unemployment benefits and pre-retirement programs.

Push factors: the unemployment rate of workers age 50-64 years as percentage was obtained from Eurostat (Eurostat, 2019a). The OECD index of employment protection legislation (EPL) is a summary indicator measuring the general assessment of the strength of labor market regulation combining measures of job protection (OECD, 2019a). The second version of the EPL index, which describes the protection of workers against individual and collective dismissals based on 12 items was used. The index ranges from o- 6 and higher scores indicate stricter regulations.

Need factors: the net replacement rate was defined as the individual net pension entitlement divided by net pre-retirement earnings, taking into account personal income taxes and social security contributions paid by workers and pensioners. The average net replacement rate was drawn out of several OECD Pensions at a Glance reports (OECD, 2009, 2011, 2013, 2015).

Maintain factors: lifelong learning is firstly measured in 2007 with the participation rate in job-related non-formal education and training among workers aged 55-64 years by Eurostat (Eurostat, 2019b). Job-related non-formal education is defined as learning activities outside the formal education system, such as courses, workshops, or guided on-the-job training to obtain knowledge and learn new skills needed for a current or future job. Furthermore, the active labor market expenditures (ALMP) as percentage of the GDP based on OECD data were considered (OECD, 2019b). ALMP's intention is to help unemployed back to work by providing training or employment and recruitment incentives. Additionally, sheltered employment and rehabilitation expenditures as percentage of GDP by the OECD were taken into account (OECD, 2019b). These expenditures cover typically relatively disadvantaged target groups (long-term unemployed, social assistance claimants, or people on disability benefit) and influence the probability and time interval of returning to work by improving health.

\section{Statistical analysis}

Discrete-time event-history analyses with a categorical outcome (involuntary work exit/ voluntary work exit/ employed) were conducted separately for each country. To model a curvilinear shape of the hazard rate, age as well as agesquared were included in the models. For each possible outcome, (involuntary work exit, voluntary work exit, and staying employed) the country-specific estimate and standard error (SE) was obtained. The country-specific estimate was the social gradient in work exit, which is the contrast in the average probability between lower and higher educated workers of exiting work. For example, a social gradient of 0.02 says that lower educated workers are on average about 
2 percentage points more likely to exit work than higher educated workers. On the contrary, a social gradient of -0.02 means that higher educated workers are more likely to exit work than lower educated workers.

To analyze (1) cross-national differences in the risk of labor market exit between high and low educated and if (2) country specific institutional factors can explain these differences, a two-step meta-analytic approach was used (Mills and Präg, 2016). Due to the limited number of countries $(\mathrm{N}<30)$ and the design of the dependent variable, this approach instead of a multilevel analysis is preferred, as the standard errors of country-level effects are underestimated if the number of countries is small (Bryan and Jenkins, 2016). The meta-analysis approach offers a more conservative test of hypotheses resulting in fewer incorrect rejections of a true null hypothesis (Brons et al., 2017).

First, a meta-analysis was performed in which all country-specific estimates and SEs of the time discrete event history model were included, to test whether there is a social gradient in type of work exit and if this gradient varies across countries. Meta-analysis provides a measure for between-country heterogeneity $\left(\mathrm{I}^{2}\right)$ ranging from $0-100 . \mathrm{I}^{2}$ essentially indicates the percentage of observed total variation across countries that is due to true heterogeneity rather than chance. Higgins et al. (2003) set benchmarks for $\mathrm{I}^{2}$ and considered 50\% and $75 \%$ as moderate and high heterogeneity between countries (Higgins et al., 2003). Three meta-analyses - namely, one for each type of work exit - are reported. Second, if significant between-country heterogeneity existed, a random-effects meta-regression was estimated. This regressed the country-specific social gradients in type of work exit on each country-level indicator separately (Harbord and Higgins, 2008). The sample size is the number of countries, $N=15$. Countries with a larger sample size had more influence because countries are inversely weighted to the precision of their effect estimate as indicated by their SE and a random effect variance component, which is an estimate of the between-study variance (Brons et al., 2017).

\section{Results}

\section{Descriptive Results}

Across all countries, two third of respondents were employed, with the highest share in Estonia (82\%) and the lowest in France (59\%) (see Table 1). Most workers exited the labor market voluntarily and only $9 \%$ involuntarily, whereby the average age of involuntary work exit was 58.8 years and by that more than three years earlier than a voluntary work exit with 62.0 years. In Portugal and Spain, most older workers had low levels of education. In Denmark and Belgium, the majority of older workers were highly educated. Most respondents were married and half of the sample was female. Country differences existed on the macro-level as well (see Table 2). PLMP spending was on 
TABLE 1. Characteristics of the sample. Mean in percentage and SD in parentheses.

\begin{tabular}{|c|c|c|c|c|c|c|c|c|c|c|}
\hline Country & $\mathrm{N}$ & $\begin{array}{l}\text { Involuntary } \\
\text { work exit }\end{array}$ & $\begin{array}{l}\text { Voluntary } \\
\text { work exit }\end{array}$ & Employed & $\begin{array}{c}\text { Low } \\
\text { education }\end{array}$ & $\begin{array}{l}\text { Medium } \\
\text { education }\end{array}$ & $\begin{array}{c}\text { High } \\
\text { education }\end{array}$ & Female & Married & $\begin{array}{l}\text { Age at last } \\
\text { observation }\end{array}$ \\
\hline Austria & 948 & 9.1 & 30.1 & 60.9 & 14.0 & $49 \cdot 3$ & 36.7 & 48.1 & 71.3 & $58.4(3.2)$ \\
\hline Belgium & 2,179 & 11.4 & 24.9 & 63.7 & 25.4 & 30.4 & 44.2 & 49.2 & 74.5 & $58.3(3.6)$ \\
\hline Czech Republic & 1,238 & 11.3 & 28.9 & 59.8 & 32.2 & 50.0 & 17.8 & 50.5 & 77.8 & $58.8(3.1)$ \\
\hline Denmark & 1,997 & 8.0 & 18.7 & 73.4 & 10.0 & 38.0 & 52.0 & 50.5 & 76.7 & $59.5(4.1)$ \\
\hline Estonia & 1,974 & 8.5 & 9.8 & 81.7 & 10.0 & 58.7 & 31.3 & 56.3 & 69.4 & $59.6(4.2)$ \\
\hline France & 1,627 & 9.8 & 31.5 & 58.6 & 19.8 & 47.1 & 33.1 & $53 \cdot 3$ & 72.3 & $58.6(3.4)$ \\
\hline Germany & 1,873 & 7.6 & 19.4 & 73.0 & 5.0 & 57.9 & 37.1 & 51.9 & 80.2 & $59.4(3.8)$ \\
\hline Italy & 1.186 & 8.2 & 17.8 & 74.0 & 41.0 & 40.7 & 18.3 & 43.1 & 84.9 & $59.1(3.8)$ \\
\hline Netherlands & 1,016 & $9 \cdot 3$ & 24.6 & 66.1 & 30.8 & 30.5 & 38.7 & 46.4 & 85.5 & $59.3(3.7)$ \\
\hline Poland & 409 & 13.7 & 27.6 & 58.7 & 13.7 & 69.9 & 16.4 & 46.0 & 86.1 & $59.0(3.5)$ \\
\hline Portugal & 268 & 19.0 & 14.9 & 66.0 & 69.0 & 16.4 & 14.6 & 53.0 & 86.9 & $59.4(3.3)$ \\
\hline Slovenia & 630 & 7.8 & $17 \cdot 3$ & 74.9 & 11.3 & 56.0 & 32.7 & 52.7 & 87.1 & $57.5(3.0)$ \\
\hline Spain & 1,369 & 12.6 & 20.7 & 66.6 & 56.2 & 22.6 & 21.2 & 44.9 & 83.9 & $59.9(3.8)$ \\
\hline Sweden & 1,699 & 5.9 & 32.8 & 61.3 & 25.4 & 36.8 & 37.7 & 54.6 & 78.9 & $61.8(3.9)$ \\
\hline Switzerland & 1,303 & 4.6 & 24.8 & 68.8 & $14 \cdot 3$ & 64.9 & 20.9 & 50.8 & 73.5 & $60.8(3.8)$ \\
\hline Total & 19,716 & 9.1 & 22.9 & 68.0 & 22.3 & 44.5 & 33.2 & 50.5 & 77.6 & $59.4(3.9)$ \\
\hline
\end{tabular}


TABLE 2. Institutional characteristics of the sample.

\begin{tabular}{|c|c|c|c|c|c|c|c|c|c|}
\hline \multirow[b]{2}{*}{ Country } & \multicolumn{2}{|c|}{ Pull factors } & \multicolumn{2}{|c|}{ Push factors } & \multicolumn{2}{|c|}{ Need factors } & \multicolumn{3}{|c|}{ Maintain factors } \\
\hline & PLMP & $\begin{array}{c}\text { Formal } \\
\text { retirement } \\
\text { age }\end{array}$ & $\begin{array}{l}\text { Unemployment } \\
\text { rate }\end{array}$ & $\begin{array}{l}\text { EPL- } \\
\text { index }\end{array}$ & $\begin{array}{l}\text { Net replacement } \\
\text { rate }\end{array}$ & $\begin{array}{c}\text { Early } \\
\text { retirement } \\
\text { age }\end{array}$ & $\begin{array}{l}\text { Lifelong } \\
\text { learning }\end{array}$ & ALMP & $\begin{array}{c}\text { Rehabilitation } \\
\text { expenditures }\end{array}$ \\
\hline Austria & 1.38 & 62.50 & 4.70 & 2.62 & 93.20 & 59.50 & 14.70 & 0.59 & 0.04 \\
\hline Belgium & 2.34 & 64.50 & 3.80 & 2.82 & 63.10 & 60.00 & 12.00 & 0.63 & 0.11 \\
\hline Czech Republic & 0.19 & 64.25 & 5.00 & 2.97 & 62.20 & 59.50 & 20.40 & 0.24 & 0.06 \\
\hline Denmark & 2.59 & 65.00 & 5.40 & 2.56 & 54.10 & 60.00 & 23.50 & 1.64 & 0.49 \\
\hline Estonia & 0.48 & 63.00 & 11.20 & 2.11 & 58.30 & 60.00 & 24.50 & 0.22 & 0.00 \\
\hline France & 2.11 & 60.00 & 6.10 & 2.73 & 68.80 & 57.00 & 11.20 & 0.95 & 0.08 \\
\hline Germany & 2.19 & 65.00 & 12.10 & 2.95 & 71.80 & 63.00 & 20.70 & 1.12 & 0.14 \\
\hline Italy & 0.61 & 62.50 & 4.00 & 3.15 & 88.80 & 57.00 & 6.90 & 0.60 & 0.00 \\
\hline Netherlands & 1.83 & 65.00 & 3.70 & 2.92 & 84.10 & 65.00 & 19.70 & 1.26 & 0.52 \\
\hline Poland & 0.51 & 62.50 & 7.50 & 2.41 & 68.20 & 62.50 & 5.90 & 0.50 & 0.18 \\
\hline Portugal & 1.37 & 65.00 & 11.00 & 3.49 & 69.20 & 65.00 & 7.50 & 0.58 & 0.04 \\
\hline Slovenia & 0.91 & 64.00 & 7.00 & 2.82 & 85.40 & 58.00 & 11.00 & 0.35 & 0.03 \\
\hline Spain & 1.47 & 65.00 & 7.40 & 2.76 & 88.30 & 60.00 & 8.90 & 0.73 & 0.03 \\
\hline Sweden & 1.32 & 65.00 & 4.50 & 2.58 & 68.20 & 61.00 & 48.70 & 1.03 & 0.20 \\
\hline Switzerland & 0.95 & 64.50 & $3 \cdot 30$ & 2.18 & 67.30 & 62.50 & 26.60 & 0.70 & 0.22 \\
\hline Mean & 1.35 & 63.85 & 6.45 & 2.74 & 72.73 & 60.67 & 17.48 & 0.74 & 0.14 \\
\hline (SD) & $(0.74)$ & $(1.46)$ & $(2.91)$ & $(0.35)$ & $(12.2)$ & $(2.51)$ & (11.0) & (o.39) & $(0.16)$ \\
\hline
\end{tabular}


average $1.35 \%$ of GDP, ranging from $0.19 \%$ in Czech Republic to $2.34 \%$ in Belgium. Formal retirement age was 65 years in most countries and early retirement age was on average 3 years before the formal one. Employment protection was the lowest in Estonia and the highest in Portugal in 2004. Older workers' participation in lifelong learning varied greatly, ranging from $6.9 \%$ in Italy to $48.7 \%$ in Sweden.

\section{Social gradient in work exit}

The results of the discrete-time event-history models showed that a social gradient in work exit existed in most countries. The average probability of an involuntary work exit over all countries was 2 percentage points (pp) higher for low educated compared to high educated workers (see Figure $3 \mathrm{a}$ ). The social gradient was the smallest in Sweden, the Netherlands, and Denmark, and greatest in the Czech Republic, Portugal, and Germany. Between-country heterogeneity was moderate with $61 \%$, and this is substantively relevant because almost two third of observed total variation across countries is due to real heterogeneity rather than chance and may be explained by institutional factors. Hypothesis Hia that the lower educated have a higher risk of involuntary work exit was supported in most countries, except Poland and Switzerland, where no differences were not significantly different from o. Only small differences between educational level and voluntary work exit were found (see figure $3 \mathrm{~b}$ ). On average, lower educated had a 1 pp higher probability of voluntarily exiting work than higher educated workers. The probability was the highest in Slovenia, Austria, and Czech Republic. However, in most countries no significant differences existed in voluntary work exit between the low and high educated. Hypothesis $H_{1} b$ which stated that the higher educated have a higher risk of voluntary work exit was not supported. Moreover, the opposite was the case in seven countries or no differences in the risk of voluntary work exit existed. Overall, the average probability of staying employed was 3 pp lower for lower-educated workers compared to higher-educated workers (see Figure 3c). This gradient was the smallest in Denmark, Spain, and Germany and largest in Slovenia, Austria and Czech Republic. No significant differences existed in The Netherlands, Poland and Portugal. Between-country heterogeneity was high, with an $\mathrm{I}^{2}$ of $77.8 \%$.

\section{Institutional factors and the social gradient in work exit}

To test if the social gradient in work exit is associated with different types of institutional factors, meta-regressions were estimated in which the country-specific social gradients in type of work exit were regressed on country-level indicators (Harbord and Higgins, 2008).

Pull factors did not explain any variance of the social gradient in work exit (see appendix Table 3). Passive labor market expenditures (PLMP) were not 
(a)

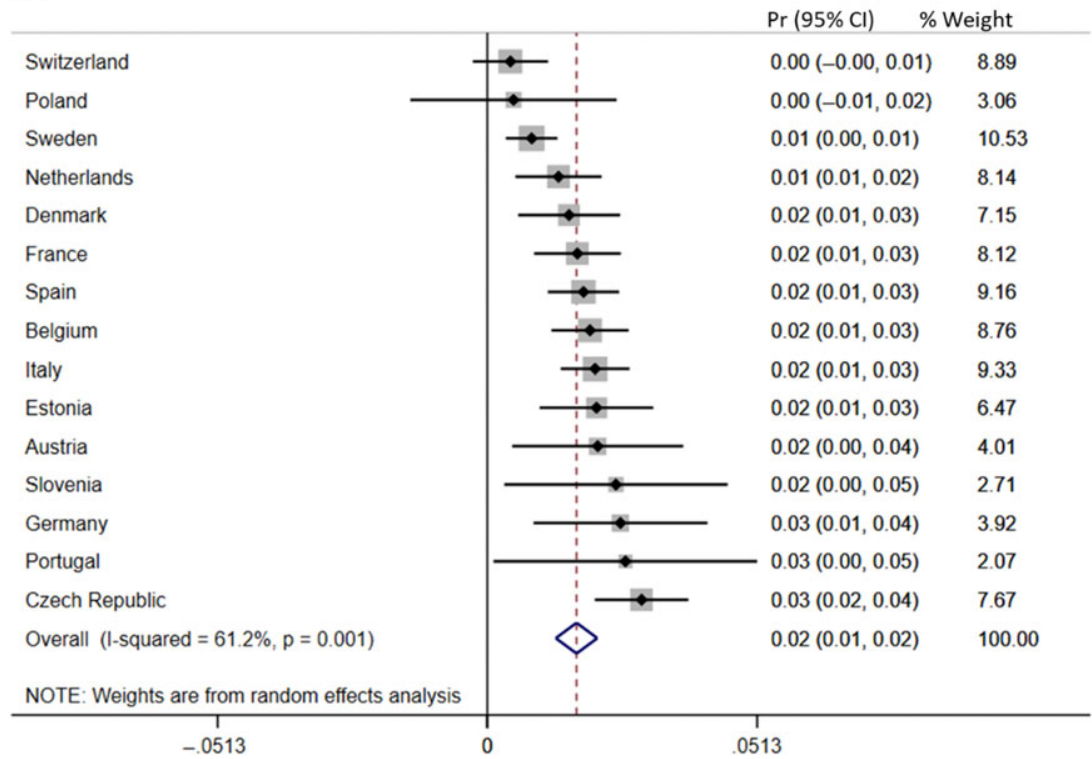

FIGURE 3a: Social gradient in involuntary work exit. Results of a random effects meta-analysis.

(b)

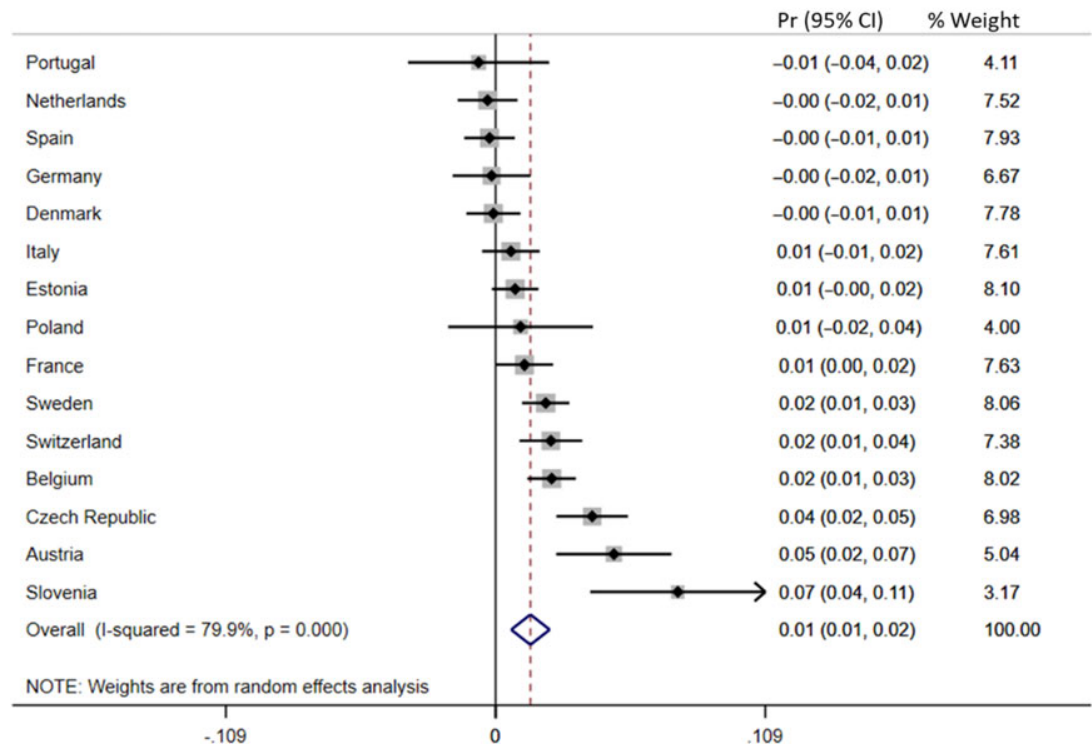

FIGURE 3b: Social gradient in voluntary work exit. Results of a random effects meta-analysis. 
(c)

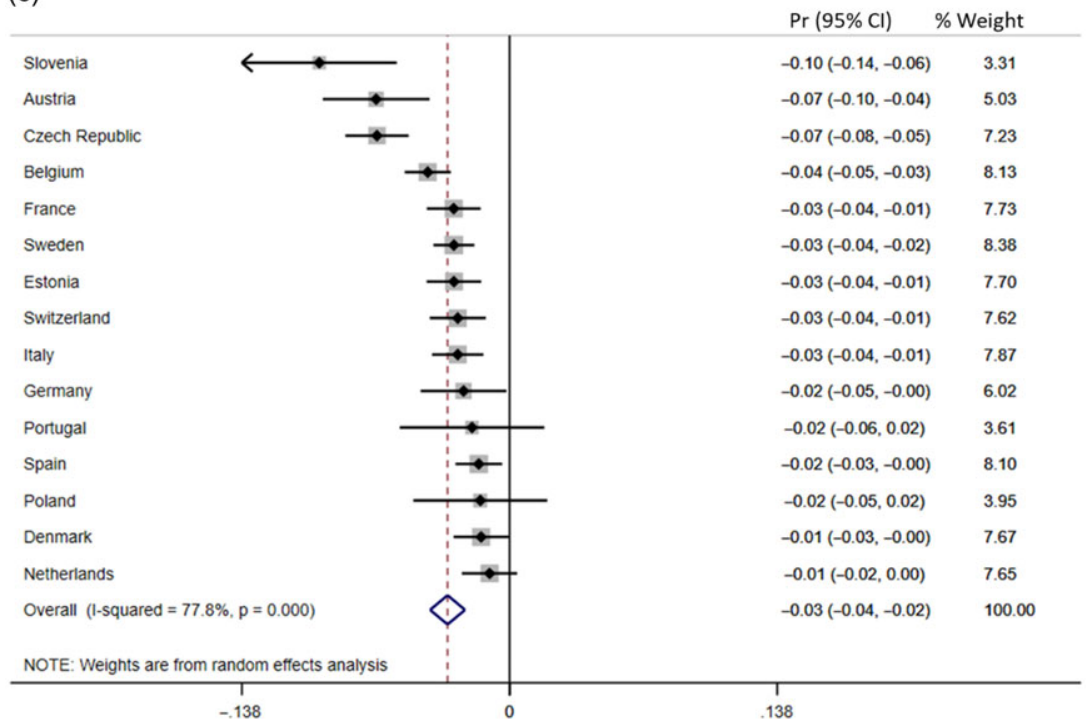

FIGURE 3c: Social gradient in staying employed. Results of a random effects meta-analysis.

associated with the social gradient in type of work exit. Hypothesis $\mathrm{H}_{2} a$ which stated that pull factors reduce the social gradient in voluntary and involuntary work exit was not supported. Hypothesis $\mathrm{H}_{2} b$ stated that push factors are associated with an increase in the social gradient in involuntary work exit. Only the EPL index but not the old-age unemployment rate was associated with a social gradient in involuntary work exit. Stricter employment protection was associated with a higher social gradient in involuntary work exit (see Figure 4a). Hence, hypothesis $\mathrm{H}_{2} b$ which had posited that push factors increase the social gradient in involuntary work exit was not rejected.

Likewise, need factors could not explain the social gradient in work exit. The net replacement rate was not associated with the social gradient in work exit. Thus, Hypothesis $\mathrm{H}_{2} \mathrm{c}$ that need factors are associated with an increase in the social gradient in employment was not supported. However, maintain factors - namely, lifelong learning, active labor market expenditures (ALMP), and rehabilitation expenditures - were associated with a smaller social gradient in type of work exit, but effect sizes were only moderate. A higher participation of older workers in lifelong learning was associated with a decrease in the social gradient in involuntary work exit but the effect size was small (see Figure 4b). Higher spending on ALMP was associated with a smaller social gradient in voluntary work exit (see Figure 4c) and with a lower social gradient in employment (see Figure $4 \mathrm{~d}$ ). Furthermore, higher expenditures in sheltered employment and rehabilitation as percentage of GDP were associated with a smaller gradient 


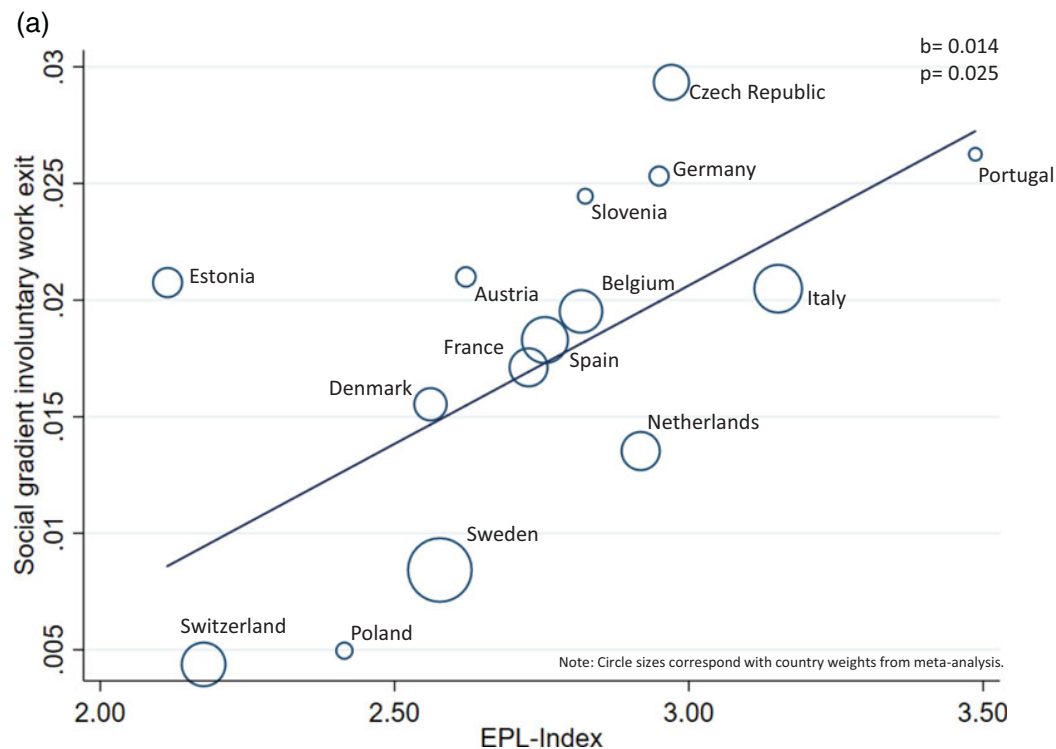

FIGURE 4a: Association between social gradient in involuntary work exit and EPL index.

(b)

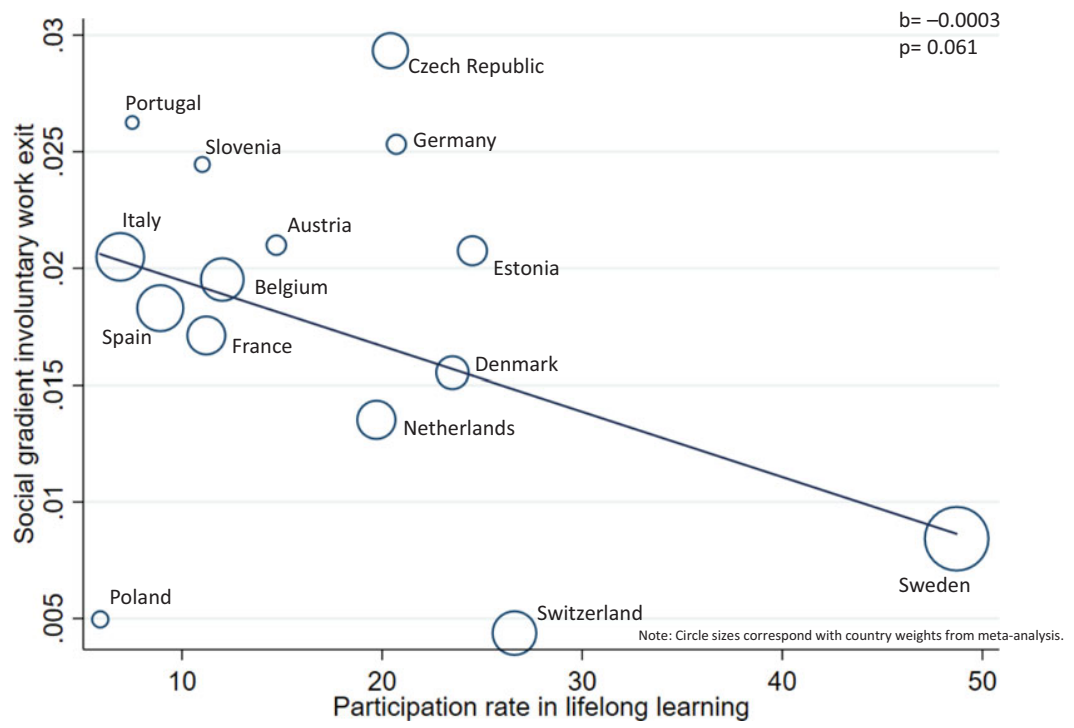

FIGURE 4b: Association between social gradient in involuntary work exit and older workers' participation rate in lifelong learning. 
(d)

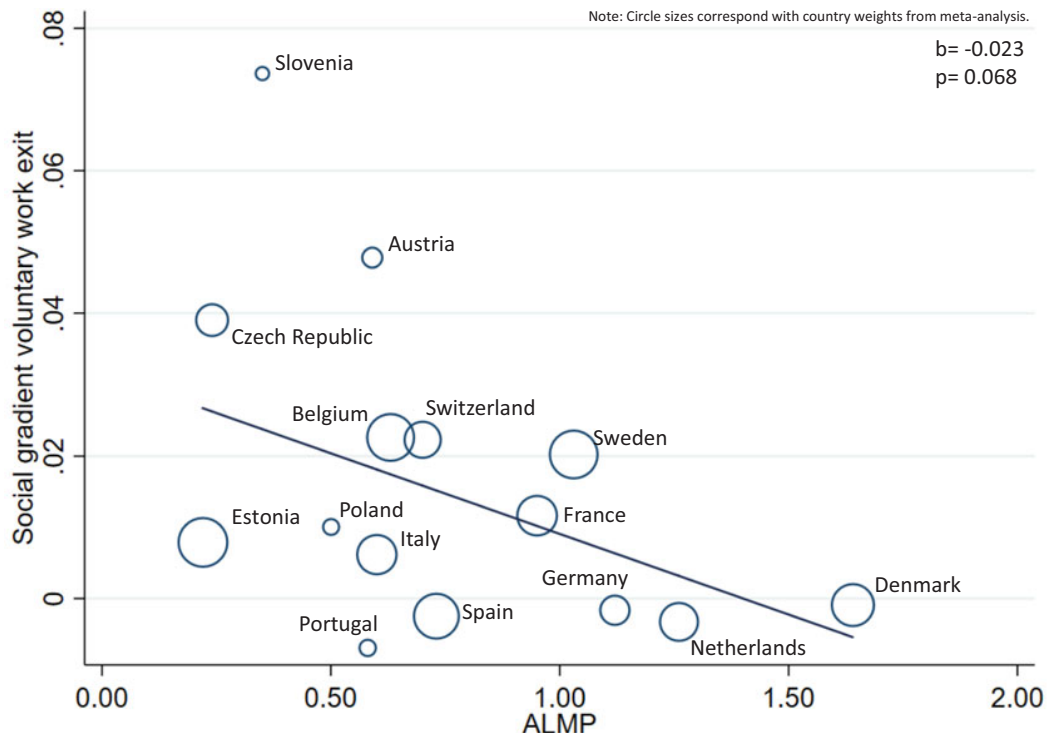

FIGURE 4c: Association between social gradient in voluntary work exit and active labor market expenditures as percentage of GDP.

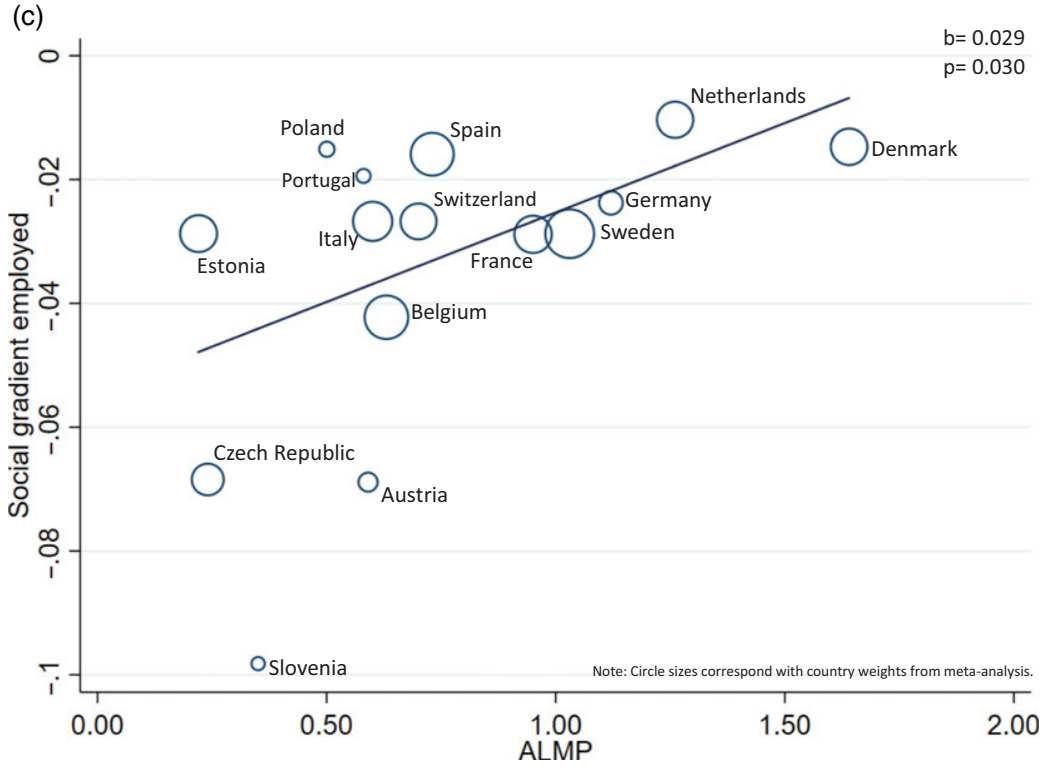

FIGURE 4d: Association between social gradient in staying employed and active labor market expenditures as percentage of GDP. 


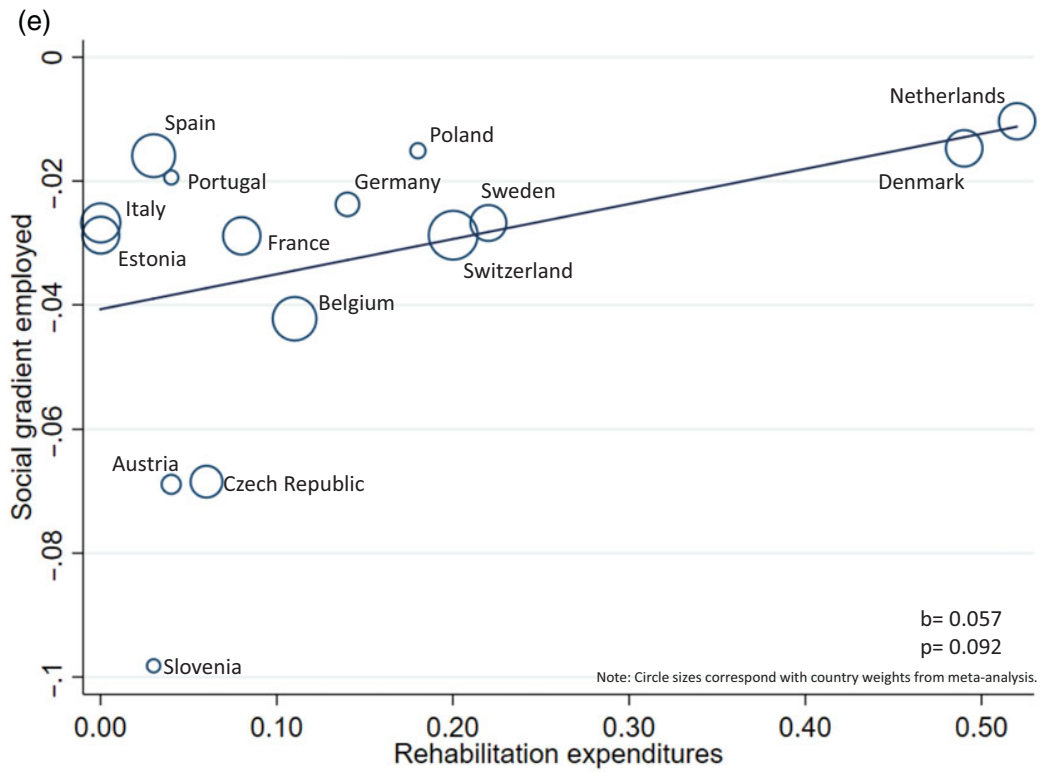

FIGURE 4e: Association between social gradient in staying employed and rehabilitation expenditures as percentage of GDP.

in staying employed (see Figure 4e). Hypothesis $\mathrm{H}_{2} d$, that maintain factors decrease the social gradient in work exit, was supported.

\section{Sensitivity Analysis}

As a robustness test we added self-rated health as a control variable in the discrete-time event history models. In almost all countries, poorer self-rated health was associated with an increased probability of an involuntary work exit but not of a voluntary exit. Educational differences remained significant but effect sizes became slightly smaller (see Figure 5a-c and Table 4 in appendix). The association between the macro indicators and type of work exit became insignificant when controlling for health which might be due to the smaller effect sizes attributed to education. This finding underpins that health seems to be a mediator rather than a confounder in this relationship.

Furthermore, analyses were estimated for men and women separately as some countries (for instance, Poland, Austria, Italy, and Slovenia) have gendered retirement schemes. The average probability of an involuntary work exit across all countries was $2 \mathrm{pp}$ higher for lower-educated compared to higher-educated workers for men and 1 pp higher for women (see Figure $6 a-7 c$ in the Appendix). Only small differences existed: for example, German lower-educated men had the highest probability of an involuntary work exit, and higher-educated Dutch women had a higher probability of a voluntary work exit. It seems 
that the way in which education influences work exit is largely the same for women and men, which is in line with previous research ( $\operatorname{Radl,~2013;~}$ Riekhoff and Järnefelt, 2017). Nevertheless, the gendered policy structure on the macro-level led to slightly different results for men and women (see Table 5 and 6 in appendix). Pull factors, especially higher PLMP, were associated with a lower social gradient in voluntary work exit and in staying employed among women. The association between maintain factors and the social gradient in work exit was almost the same for men and women. Only ALMPs were associated with a smaller social gradient in any type of work exit among women but not among men. Also push factors - namely, the EPL index indicating stricter employment protection - led to an increasing social gradient in involuntary work exit only for men.

Additionally, we estimated the associations between the social gradients and the average of the institutional factors over the observation period, as it is not possible to consider time-varying macro indicators in random meta-regressions. As there is not much variation over time in most indicators, all associations remain significant or became even stronger except the association between the social gradient in staying employed and rehabilitation expenditures (see Table 7 in the Appendix). The correlation between the macro indicators was mostly modest to moderate (see Table 8 and 9 in the Appendix). Furthermore, the social gradient was estimated with only considering involuntary retirement pathways and excluding unemployment work exits. Thus, the social gradient in involuntary work exit was slightly larger in most countries but also became insignificant in some countries due to the smaller sample size (see Figure $8 \mathrm{a}-\mathrm{c}$ in the Appendix).

Additionally, the association between the social gradient in involuntary work exit and older workers' participation rate in lifelong learning was estimated without Sweden and results became insignificant. Sweden thus might be an outlier based on the used data from 2007. However, considering newer numbers of the Adult Education Survey from 2016, the participation rate of older workers in lifelong learning increased on average by 10\% among countries (see Figure 9 in the Appendix).

\section{Conclusions and Discussion}

The aim of the study was to identify educational differences in voluntary and involuntary work exit and if these differences vary by institutional characteristics. Educational inequalities existed primarily in involuntary work exit. In 13 out of 15 European countries, lower-educated workers were more likely to exit work involuntarily than higher-educated workers. No educational differences in voluntary work exit existed in most countries. Overall, lower-educated workers were more likely to exit work than higher educated workers, especially in Slovenia, Austria, and Czech Republic. Institutional pull as well as need factors 
could not explain the social gradient in work exit. Push factors, in particular the EPL index, were associated with a social gradient in involuntary work exit. Stricter employment protection led to a higher social gradient in involuntary work exit. This effect was stronger among men than women. Strong employment protection seems to lead to an even stronger labor market segmentation between lower- and higher-educated workers, because of firms' reduced propensity to hire lower-educated workers covered by strong employment protections and collective agreements. Maintain factors led to a smaller gradient in work exit. Active labor market expenditures were associated with a smaller social gradient in voluntary work exit and staying employed. A higher participation rate in lifelong learning was linked to a smaller social gradient in involuntary work exit and higher expenditures in sheltered employment and rehabilitation were associated with a smaller gradient in staying employed. Results show that investments in job-related education, such as courses and workshops to obtain new skills, especially for lower educated workers can help to prolong working lives. Particularly for older workers, changing working conditions due to digitalization might be more challenging and further on-the-job training potentially decrease this burden. New numbers of the Adult Education Survey already show that the participation rate of older workers in lifelong learning increased on average by $10 \%$ during the last nine years among most European countries (Eurostat, 2019b).

Overall, active labor market policies providing training or employment and recruitment incentives seem to be an effective measure to reduce educational inequalities in work exit for both men and women. How to provide effective on-the-job training on the firm level might be a task for future research.

Small differences existed in voluntary work exit between men and women. For women, pull factors - namely, passive labor market expenditures offering generous benefits and preretirement programs for maintaining the living standard after work exit - were associated with a smaller gradient in voluntary work exit and staying employed. Furthermore, need factors, in particular a higher early retirement age at which pension benefits can be claimed, was associated with a decreasing social gradient in involuntary as well as voluntary work exit and an increasing in staying employed among women. Women's decision to exit the labor market voluntarily largely depends on the generosity of pension programs and compensations for forgone earnings. Men, on the other hand, seem not to be affected by institutional factors when exiting the labor market voluntarily. Women's decision to exit work might depend more on the spouses' employment status as well. Previous research showed that married women are more likely to retire early than divorced women (Finch, 2014). Analyzing the dyadic structure of labor market exit decisions and how institutional factors influence joined work exit decisions could be a task for future research.

This study contributes to previous research by empirically testing institutional factors that also include those aiming at delaying retirement and hence, 
extending the push and pull approach. Especially maintain factors which are intended to improve opportunities of older workers to stay in employment are effective measures to do so. Not only education in early life, but also further on-the-job training later can help to reduce the social gradient in involuntary work exit.

Moreover, from a social policy perspective it is important to consider work exit and not only retirement entry. Work exit also includes becoming unemployed or a homemaker, which is not covered by observing retirement entries. Social security systems must already intervene in case of a labor market exit. This can occur much earlier than retirement and lead to higher costs considering unemployment benefits besides pension claims. Using a meta-analysis, we showed that pull and need factors were not associated with a social gradient in work exit (Brons et al., 2017; Bryan and Jenkins, 2016). This result is in line with previous research using data covering the same observation period starting in the early 200os (Ebbinghaus and Hofäcker, 2013; Ebbinghaus and Radl, 2015). These findings suggest that the much-discussed increase in retirement age alone may not directly lead to an increasing social gradient in work exit. Rather, it is an interplay of various factors influencing the social gradient in different ways.

A limitation of the study is that a further distinction between types of work exit - for instance, unemployment, disability retirement, early retirement, and statutory retirement - and not only between voluntary and involuntary work exit was not possible to due to small sample sizes in most countries. Even if the allocation to voluntary and involuntary work exit were done by adopting a classification from previous research, there might still have been a risk that a self-perceived and objectively involuntary work exit might have been subjectively voluntary. However, a measure asking people if it was their own choice to exit work was not available. In addition, both questions regarding the employment status and education (ISCED) had only few non-responses compared to monetary questions. Moreover, net replacement rates likely differ by educational level which might explain the non-finding (Malter and Bösch-Supran, 2015). However, stratified replacement rates by education were not available for the countries under study. Besides, results show that pull as well as need factors could not explain the social gradient in work exit. Educational inequalities in work exit seem to be unrelated, e.g. to the unemployment rate of older workers. Another possibility could be that a higher unemployment rate might affect the social gradient in involuntary work exit differently, e.g. during a recession (Ebbinghaus and Radl, 2015). The macro-indicators were mostly measured in 2004 before the Great Recession in most European countries, and including longitudinal measures of the macro-indicators was not possible in a meta-analysis framework. In addition, a possible interplay of the indicators, e.g. high rehabilitation expenditures are likely associated with a lower unemployment rate, could not be tested. 
Nevertheless, this study showed that a social gradient in involuntary work exit is present in most European countries which can have serious negative consequences for individual workers well-being, such as poorer life satisfaction, lower self-rated health, higher risk of depression, and lower old-age income (Ebbinghaus and Radl, 2015; Heisig, 2017; Hyde et al., 2015). For lower-educated workers it is more difficult to reach the new goal of extending working lives. This may lead to rising social inequalities between lower and higher educated workers. Investments in active labor market expenditures, especially in lifelong learning and rehabilitation for lower educated, may help to reduce the social gradient in involuntary work exit. This should be considered by policymakers, employers, and trade-unions.

\section{Funding}

The SHARE data collection has been primarily funded by the European Commission through FP5 (QLK6-CT-2001-00360), FP6 (SHARE-I3: RII-CT2006-062193, COMPARE: CIT5-CT-2005-028857, SHARELIFE: CIT4-CT2006-028812) and $\mathrm{FP}_{7}$ (SHARE-PREP: $\mathrm{N}^{\circ}$ 211909, SHARE-LEAP: $\mathrm{N}^{\circ} 227822$, SHARE M4: $\mathrm{N}^{\circ}$ 261982). Additional funding from the German Ministry of Education and Research, the Max Planck Society for the Advancement of Science, the U.S. National Institute on Aging (Uo1_AGo9740-13S2, Po1_AGo05842, Po1_AGo8291, P30_AG12815, R21_AGo25169, Y1-AG-4553-01, IAG_BSRo6-11, OGHA_04-064, HHSN271201300071C) and from various national funding sources is gratefully acknowledged (see www.share-project.org).

Jana Mäcken was supported by a grant of the Forschungsnetzwerk Alterssicherung (FNA-ST-2016-04). This paper was written during a research visit by the first author at Nuffield College supported by a grant from the European Consortium for Sociological Research (ECSR). Patrick Präg was supported by a grant (no 681546, FAMSIZEMATTERS) from the European Research Council (ERC) under the European Union's Horizon 2020 research and innovation program.

\section{Acknowledgements}

Previous versions of this article were presented at the 2019 RC 28 Spring Meeting in Frankfurt, Germany, and at the 2019 Annual Meeting of the PAA in Austin, Texas. This article uses data from SHARE Waves 1, 2, 3, 4, 5, 6 and 7 (DOIs: 10.6103/SHARE.w1.700, 10.6103/ SHARE.w2.700, 10.6103/SHARE.w3.700, 10.6103/SHARE.w4.700, 10.6103/SHARE.w5.700, 10.6103/SHARE.w6.700, 10.6103/SHARE.w7.700), see Börsch-Supan et al. (2013) for methodological details.

\section{Competing interests}

The authors declare none. 


\section{Supplementary material}

To view supplementary material for this article, please visit https://doi.org/10. $1017 /$ So0 47279421000258

\section{Note}

1 Austria, Germany, Sweden, the Netherlands, Spain, Italy, France, Denmark, Switzerland, Belgium, Czech Republic, Poland, Slovenia and Estonia

\section{References}

Blossfeld, H.-P., Buchholz, S. and Kurz, K. (2011). Aging populations, globalization and the labor market: Comparing late working life and retirement in modern societies. (H.-P. Blossfeld, S. Buchholz. and K. Kurz, Eds.). Cheltenham: Edward Elgar.

Börsch-Supan, A., Brandt, M., Hunkler, C., Kneip, T., Korbmacher, J., Malter, F., ... Zuber, S. (2013). Data Resource Profile: The Survey of Health, Ageing and Retirement in Europe (SHARE). International Journal of Epidemiology, 42(4), 992-1001.

Brons, M. D. A., Liefbroer, A. C. and Ganzeboom, H. B. G. (2017). Parental Socio-Economic Status and First Union Formation: Can European Variation Be Explained by the Second Demographic Transition Theory? European Sociological Review, 33(6), 809-822.

Bryan, M. L. and Jenkins, S. P. (2016). Multilevel Modelling of Country Effects: A Cautionary Tale. European Sociological Review, 32(1), 3-22.

Carr, E., Fleischmann, M., Goldberg, M., Kuh, D., Murray, E. T., Stafford, M., ... Head, J. (2018). Occupational and educational inequalities in exit from employment at older ages: evidence from seven prospective cohorts. Occupational and Environmental Medicine, 75(5), 369-377.

De Preter, H., Van Looy, D. and Mortelmans, D. (2013). Individual and institutional push and pull factors as predictors of retirement timing in Europe: A multilevel analysis. Journal of Aging Studies, 27(4).

Ebbinghaus, B. and Hofäcker, D. (2013). Reversing Early Retirement in Advanced Welfare Economies A Paradigm Shift to Overcome Push and Pull Factors. Comparative Population Studies, 38(4).

Ebbinghaus, B. and Radl, J. (2015). Pushed out prematurely? Comparing objectively forced exits and subjective assessments of involuntary retirement across Europe. Research in Social Stratification and Mobility, 41, 115-130.

Engelhardt, H. (2012). Late Careers in Europe: Effects of Individual and Institutional Factors. European Sociological Review, 28(4), 550-563.

Eurostat. (2019a). Arbeitslosenquote nach Geschlecht, Alter, und Staatsangehörigkeit. Retrieved from http://appsso.eurostat.ec.europa.eu/nui/submitViewTableAction.do

Eurostat. (2019b). Participation rate in job-related non-formal education and training by type and age. Retrieved from https://ec.europa.eu/eurostat/web/products-datasets/product? code=trng_aes_121

Finch, N. (2014). Why are women more likely than men to extend paid work? The impact of work-family life history. European Journal of Ageing, 11(1), 31-39.

Fisher, G. G., Chaffee, D. S. and Sonnega, A. (2016). Retirement Timing: A Review and Recommendations for Future Research. Work, Aging and Retirement, 2(2), 230-261.

Gruber, J. and Wise, D. (2000). Social security programs and retirement around the world. In Research in Labor Economics (pp. 1-40). Emerald.

Harbord, R. M. and Higgins, J. P. T. (2008). Meta-regression in Stata. Stata Journal, 8(4), 493519.

Heisig, J. P. (2017). Late-career Risks in Changing Welfare States. Amsterdam University Press. 
Hess, M., König, S. and Hofäcker, D. (2016). Retirement transitions under changing institutional conditions: towards increasing inequalities? Comparing evidence from 13 countries. In Delaying Retirement (pp. 363-378). Springer.

Higgins, J. P. T., Thompson, S. G., Deeks, J. J. and Altman, D. G. (2003). Measuring inconsistency in meta-analyses. BMJ, 327(7414), 557-560.

Hofäcker, D. and Naumann, E. (2015). The emerging trend of work beyond retirement age in Germany. Zeitschrift Für Gerontologie Und Geriatrie, 48(5), 473-479.

Hofäcker, D. and Radl, J. (2016). Retirement Transitions in Times of Institutional Change: Theoretical Concept. Delaying Retirement, 1-21.

Hofäcker, D., Schroeder, H., Li, Y., Flynn, M., Schröder, H., Li, Y. and Flynn, M. (2016). Trends and Determinants of Work-Retirement Transitions under Changing Institutional Conditions: Germany, England and Japan compared. Journal of Social Policy, 45(1), $39-64$.

Hofäcker, D. and Unt, M. (2013). Exploring the 'new worlds' of (late?) retirement in Europe. Journal of International and Comparative Social Policy, 29(2), 163-183.

Hutchens, R. (1999). Social security benefits and employer behavior: evaluating social security early retirement benefits as a form of unemployment insurance. International Economic Review, 40(3), 659-678.

Hyde, M., Hanson, L. M., Chungkham, H. S., Leineweber, C. and Westerlund, H. (2015). The impact of involuntary exit from employment in later life on the risk of major depression and being prescribed anti-depressant medication. Aging \& Mental Health, 19(5), $381-389$.

Johansson, E., Leijon, O., Falkstedt, D., Farah, A., Hemmingsson, T., Leinonen, T. and Schuring, M. (2012). Educational differences in disability pension among Swedish middle-aged men: Role of factors in late adolescence and work characteristics in adulthood. Journal of Epidemiology and Community Health, 66(10), 901-907.

Mäcken, J., Präg, P., Hess, M. and Ellwardt, L. (2020). Replication materials to: 'Educational inequalities in labor market exit of older workers in 15 European countries,' Open Science Framework, doi: 10.17605/OSF.IO/9J56G.

Malter, F. and Bösch-Supran, A. (2015). SHARE Wave 5: Innovations \& Methodology. Munich: MEA, Max Planck Institute for Social Law and Social Policy.

Mills, M. C. and Präg, P. (2016). Methodological Advances in Cross-National Research: Multilevel Challenges and Solutions. European Sociological Review, 32(1), 1-2.

Murphy, D. P., Mermin, G. B. T. and Johnson, R. W. (2007). Why Do Boomers Plan to Work Longer? The Journals of Gerontology: Series B, 62(5), S286-S294.

OECD (2009). Pensions at a Glance 2009. Paris. Retrieved from https://www.oecd-ilibrary.org/ finance-and-investment/pensions-at-a-glance-2009_pension_glance-2009-en

OECD (2011). Pensions at a Glance 2011. Paris. Retrieved from https://www.oecd-ilibrary.org/ finance-and-investment/pensions-at-a-glance-2011_pension_glance-2011-en

OECD (2013). Pensions at a Glance 2013. Paris. Retrieved from https://www.oecd-ilibrary.org/ finance-and-investment/pensions-at-a-glance-2013_pension_glance-2013-en

OECD (2015). Pensions at a Glance 2015. Paris. https://doi.org/10.1787/pension_glance-2015-en

OECD (2019a). OECD Indicators of Employment Protection. Retrieved from https://www. oecd.org/employment/emp/oecdindicatorsofemploymentprotection.htm

OECD (2019b). Public expenditure and participant stocks on LMP. Retrieved from https:// stats.oecd.org/

Potočnik, K., Tordera, N. and Peiró, J. M. (2009). The role of human resource practices and group norms in the retirement process. European Psychologist, 14(3), 193-206.

Radl, J. (2013). Labour market exit and social stratification in Western Europe: The effects of social class and gender on the timing of retirement. European Sociological Review, 29(3), 654-668.

Reeuwijk, K. G., van Klaveren, D., van Rijn, R. M., Burdorf, A. and Robroek, S. J. (2017). The influence of poor health on competing exit routes from paid employment among older 
workers in 11 European countries. Scandinavian Journal of Work, Environment \& Health, 43(1), 24-33.

Riekhoff, A.-J. and Järnefelt, N. (2017). Gender Differences in Retirement in a Welfare State with High Female Labour Market Participation and Competing Exit Pathways. European Sociological Review, 33(6), 791-807.

Robroek, S., Rongen, A., Arts, C., Otten, F., Burdorf, A. and Schuring, M. (2015). Educational inequalities in exit from paid employment among Dutch workers: The influence of health, lifestyle and work. PLoS ONE, 10(8), 1-12.

Scharn, M., Sewdas, R., Boot, C. R. L., Huisman, M., Lindeboom, M. and van der Beek, A. J. (2018). Domains and determinants of retirement timing: A systematic review of longitudinal studies. BMC Public Health, 18(1), 1083.

Schreurs, B., Van Emmerik, H., De Cuyper, N., Notelaers, G. and De Witte, H. (2010). Job demands-resources and early retirement intention: Differences between blue-and white-collar workers. Economic and Industrial Democracy, 32(1), 47-68.

Schuring, M., Robroek, S. J., Lingsma, H. F. and Burdorf, A. (2015). Educational differences in trajectories of self-rated health before, during, and after entering or leaving paid employment in the European workforce. Scandinavian Journal of Work, Environment \& Health, $41(5), 441-450$.

Schuring, M., Schram, J., Robroek, S. J. W. and Burdorf, A. (2019). The contribution of health to educational inequalities in exit from paid employment in five European regions. Scandinavian Journal of Work, Environment \& Health, 45(4), 346-355.

van Rijn, R. M., Robroek, S. J. W., Brouwer, S., Burdorf, A., Rijn, R. M., Robroek, S. J. W., . . Burdorf, A. (2014). Influence of poor health on exit from paid employment: a systematic review. Journal of Occupational and Environmental Medicine, 71(4), 295-301.

van Solinge, H. and Henkens, K. (2007). Involuntary Retirement: The Role of Restrictive Circumstances, Timing, and Social Embeddedness. The Journals of Gerontology: Series $B, 62(5), \mathrm{S}_{295}-\mathrm{S}_{303}$.

Visser, M., Gesthuizen, M., Kraaykamp, G. and Wolbers, M. H. J. (2016). Inequality among Older Workers in the Netherlands: A Life Course and Social Stratification Perspective on Early Retirement. European Sociological Review, 32(3), 370-382.

Wahrendorf, M., Dragano, N. and Siegrist, J. (2013). Social Position, Work Stress, and Retirement Intentions: A Study with Older Employees from 11 European Countries. European Sociological Review, 29(4), 792-802. 